\title{
Changes in the blood indicators of experimental animals by introduction of the components based on lanthanide ions and calcium into the zone of a femoral fracture
}

\author{
I.F. Akhtiamov ${ }^{1}$, F.V. Shakirova ${ }^{2}$, D.A. Korobeynikova ${ }^{2}$, H.Zh. Han ${ }^{1}$, E.I. Sidoruk ${ }^{1}$ \\ ${ }^{1}$ Kazan State Medical University, Kazan, Russia \\ ${ }^{2}$ Kazan Bauman State Academy of Veterinary Medicine, Kazan, Russia
}

\begin{abstract}
Introduction Reduction of time to restore bone integrity remains one of the main problems in traumatology and orthopedics. To solve this problem, various kinds of components have been used, one of which are bisphosphonates. This article presents an experiment, the purpose of which was to study the effect of components based on etidronates of lanthanide or calcium on blood indicators by different ways of their introduction into the femoral fracture site in experimental animals. Materials and methods Studies were conducted on 75 male rats aged 5-6 months, weighing 300-350 g. A femoral fracture was modeled in all animals, and retrograde intramedullary osteosynthesis was performed. Animals were divided into 5 groups. Group 1 received no components; a component based on etidronates of lanthanide and calcium was introduced in group 2 through a catheter; group 3 had paraossal administration of etidronates of lanthanide and calcium; group 4 had paraossal introduction of a component based on etidronate calcium through a catheter; and group 5 had introduction of components based on etidronates and calcium. Animals received the investigated components twice in the fracture zone on days 3 and 5 after the operation, except the comparison group. Results In groups with a catheter, the most pronounced local inflammatory response was observed. Changes in hemoglobin concentration were observed in all groups, in the early (7 days) period. It was found that in rats which were injected with components containing lanthanides, the average content of hemoglobin, erythrocytes and leukocytes were identical to those of group 1. Conclusion The study revealed that the components, which include lanthanide ions do not cause negative changes in the rat blood according to hematological tests.
\end{abstract}

Keywords: rat, femoral bone, hematological values

One of the important areas of traumatology is restoration and repair of damaged bone tissue $[1,2]$. In addition to improving osteosynthesis, medicinal compounds that stimulate reparative processes have been searched currently. Bone regeneration may be stimulated by components that have osteoinductive and osteoconductive properties, do not cause toxic and allergic reactions of the body [3]. Nowadays, various types of drugs aimed at stimulating osteogenesis have been known, such as "Osteogenon" [4, $5,6]$. It consists of hydroxyapatite and ossein and has been widely used for osteoporosis [7]. Another drug, "Valpan", based on hydroxyapatite and collagen, has been applied to accelerate osteogenesis [8]. Some authors have studied the injection of the biocomposite "LitAr" and established its positive effect in delayed osteoreparation [9].

Preparations that include bisphosphonates have also found a widespread use. Their action is aimed at decrease of resorption [10]. In addition, their use also normalizes the mineralization processes to increase bone mass and strength [11]. However, bisphosphonates in a state of a solution cannot be concentrated for a long time in the zone of local administration, and it remains a problematic issue in the treatment with their use[12]. Therefore, lanthanide ions have been used. These are effective catalysts of hydrolytic sciccion of phosphate-ether bonds, including strong bonds in DNA [13].

The literature on this topic provides little information about the body's response to the use of lanthanides. Therefore, the objective of our study was to study the effect of the agents based on the ethidronates of lanthanide ions and calcium on hematological parameters in different modes of their delivery to the fracture zone of the femur in experimental animals.

\section{MATERIAL AND METHODS}

The studies were carried out in accordance with GOST ISO 10993 (R) and approved by the local ethics committee at the Federal State Budgetary Educational Institution of Higher Education Kazan State Medical University of the Ministry of Health of Russia (protocol No. 10 dated December 18, 2018) [14].

Experimental animals were 75 male rats. The age of the rats was 5-6 months, weight 330-360 g. The animals formed 5 groups, 15 rats each.
An osteotomy was performed [15] in all the animals followed by retrograde nailing into the medullary canal [16]. Implants made of medical steel $12 \mathrm{X} 18 \mathrm{H} 9$ had a diameter of $0.8 \mathrm{~mm}$ and $1 \mathrm{~mm}$ with feather-like sharpening.

Group 1 did not receive any componentю Components based on etidronates of lanthanide and calcium were introduced in group 2 through a catheter; group 3 had paraossal administration of components based on

Akhtiamov I.F., Shakirova F.V., Korobeynikova D.A., Han H.Zh., Sidoruk E.I. Changes in the blood indicators of experimental animals by introduction of the components based on lanthanide ions and calcium into the zone of a femoral fracture. Genij Ortopedii, 2020, vol. 26, no 2, pp. 228-233. DOI 10.18019/1028-4427-2020-26-2-228-233 
etidronates lanthanide and calcium by injections into the fracture zone from the lateral and medial sides $[17,18]$; group 4 had paraossal introduction of a component based on calcium etidronate and (without lanthanide etidronate) through a catheter; and group 5 had paraosseous injections of the components based on calcium etidronate (without lanthanide) into the fracture zone from the lateral and medial sides. All components were introduced into the fracture zone on the $3^{\text {rd }}$ and $5^{\text {th }}$ day after the operation [19] at a dose of $0.2 \mathrm{ml}$ on each side (medially and laterally) paraossally or $0.4 \mathrm{ml}$ through the catheter.

Two groups of animals (2 and 4 ) had a pre-installed catheter in the fracture zone. To install the catheter, a hole of a diameter of $1.5 \mathrm{~mm}$ was drilled above the osteotomy zone as planned and a catheter was inserted into the hole, leading it to the medullary canal. The catheter cannula remained under the skin. An intradermal suture was applied.

During the entire experimental period, animals were monitored clinically for 30 days. Their general condition, nutritional excitability, motor activity, body temperature and local body reactions were observed.
Blood was collected to determine hematological parameters from the tail vein (v. Coccygea) in a volume of $1 \mathrm{ml}$ before surgery, on the $7^{\text {th }}, 14^{\text {th }}$ and $30^{\text {th }}$ day after surgery. To obtain reliable data, a new group of animals was taken for each term.

Erythrocyte sedimentation rate (using the Panchenkov apparatus and pipettes), hemoglobin concentration (hemometer and Sali pipettes), number of red blood cells (counts in the Goryaev chamber) and leukocytes (counts in the Goryaev chamber) were determined; morphological composition of leukocytes was determined according to the generally accepted method [20]. Axioscop-Zeiss AG microscope was used.

Statistical processing methods Digital data were processed using the SPSS 13.0 software. Using the Kolmogorov-Smirnov criterion, the normality of the distribution of indicators was evaluated. Student's test was used for pairwise comparisons. Analysis of variance was used for comparing three or more groups. Subsequent intergroup comparisons were performed using Student's test with Bonferroni correction. Significant differences were considered at $p<0.05$ [16].

\section{RESULTS}

During the clinical study, no significant changes in the general condition of experimental rats were detected. The restoration of food excitability was observed after 6 hours, and motor activity an hour after surgery. The body temperature throughout the entire period remained within the physiological norm and was on average $7{ }^{\circ} \mathrm{C}$ on day 7 (Table 1). However, in group 4 with the introduction of components based on calcium ethidronate (without lanthanides) through the catheter, changes were observed on the 30th day of the experiment; this parameter increased by $2 \%(\mathrm{p}=0.001)$.

There was an inflammatory reaction at the site of the postoperative wound, more pronounced in groups 2 with the introduction ethidronates of lanthanide and calcium through a catheter and 4 with the introduction of calcium ethidronate (without lanthanides) through a catheter. The reaction was manifested by edema, increased local temperature and exudation. All animals had moderate supporting limpness.

The analysis of blood morphological parameters revealed changes in the dynamics of the erythrocyte sedimentation rate (ESR) on the 7th day. In group 3, this indicator increased significantly by 1.8 times $(\mathrm{p}=0.016)$, and in group 5 without lanthanide ions, significant differences were observed, as this indicator increased by 1.6 times $(\mathrm{p}=0.016)$ (Table 2). In other groups, no significant changes were observed.

In group 4 with the introduction of calcium ethidronate (without lanthanide) using a catheter, ESR significantly decreased on the $14^{\text {th }}$ day by 2.6 times $(p=0.007)$ relative to group 1 without the components. On day 30 , it was found that this indicator in group 2 with the introduction of the components based on ethidronates of lanthanide and calcium through a catheter and group 3 with the paraossal administration of the components based on the ethidronates of lanthanide and calcium significantly increased by 1.8 times relative to group 1 without administration of the components $(p=0.019)$ and group 5 with a paraosseous administration of the components based on calcium ethidronate (without lanthanide $)(p=0.019)$.

Table 1

Temperature measurements in the postoperative period $\left({ }^{\circ} \mathrm{C}\right)$

\begin{tabular}{|c|c|c|c|c|c|c|}
\hline Group /Term & Before operation & 7 days & Before operation & 14 days & Before operation & 30 days \\
\hline Group 1 & $37.3 \pm 0.10$ & $37.0 \pm 0.03$ & $37.0 \pm 0.02$ & $37.1 \pm 0.05$ & $37.2 \pm 0.12$ & $37.1 \pm 0.05$ \\
\hline Group 2 & $37.1 \pm 0.09$ & $37.1 \pm 0.04$ & $37.1 \pm 0.05$ & $37.2 \pm 0.10$ & $37.1 \pm 0.05$ & $37.0 \pm 0.04$ \\
\hline Group 3 & $37.1 \pm 0.09$ & $37.0 \pm 0.03$ & $37.0 \pm 0.04$ & $37.2 \pm 0.06$ & $37.2 \pm 0.08$ & $37.2 \pm 0.11$ \\
\hline Group 4 & $37.1 \pm 0.13$ & $37.0 \pm 0.03$ & $37.2 \pm 0.08$ & $37.1 \pm 0.03$ & $37.2 \pm 0.09$ & $37.8 \pm 0.11^{*}$ \\
\hline Group 5 & $37.2 \pm 0.05$ & $37.1 \pm 0.05$ & $37.2 \pm 0.11$ & $37.1 \pm 0.03$ & $37.0 \pm 0.04$ & $37.2 \pm 0.15$ \\
\hline
\end{tabular}

Notes: ${ }^{*}$ - statistically significant differences with preoperative values at $\mathrm{p}<0.05$ 
Change in the erythrocyte sedimentation rate in the blood of animals at the stages of the study $(\mathrm{mm} / \mathrm{h})$

\begin{tabular}{|c|c|c|c|c|c|c|}
\hline Group /Term & Before operation & 7 days & Before operation & 14 days & Before operation & 30 days \\
\hline Group 1 & $0.6 \pm 0.1$ & $0.5 \pm 0.00$ & $0.5 \pm 0.00$ & $0.8 \pm 0.12$ & $0.5 \pm 0.00$ & $0.5 \pm 0.00$ \\
\hline Group 2 & $0.8 \pm 0.2$ & $0.5 \pm 0.12$ & $0.8 \pm 0.12$ & $0.6 \pm 0.10$ & $0.7 \pm 0.20$ & $0.9 \pm 0.10 \#^{* *}$ \\
\hline Group 3 & $0.3 \pm 0.00$ & $0.4 \pm 0.13$ & $0.5 \pm 0.00$ & $0.5 \pm 0.00$ & $0.5 \pm 0.00$ & $0.9 \pm 0.10^{*} \#^{* *}$ \\
\hline Group 4 & $0.9 \pm 0.1$ & $0.7 \pm 0.12$ & $0.7 \pm 0.12$ & $0.3 \pm 0.04 \#$ & $1 \pm 0.00$ & $0.6 \pm 0.12$ \\
\hline Group 5 & $0.3 \pm 0.04$ & $0.5 \pm 0.00^{*}$ & $0.4 \pm 0.04$ & $0.5 \pm 0.00$ & $0.6 \pm 0.10$ & $0.5 \pm 0.00$ \\
\hline
\end{tabular}

Notes: $*$ - significantly significant differences with preoperative values at $\mathrm{p}<0.05 ; * *$ - significantly significant differences with group No. 5 at $\mathrm{p}<0.05 ; \#-$ significantly significant differences with group No. 1 at $\mathrm{p}<0.05$

A significant decrease in the concentration of hemoglobin $(\mathrm{Hg})$ was found on the $7^{\text {th }}(\mathrm{p}=0.001)$ and on the 30th days of the experiment $(\mathrm{p}=0.007)$ in group 1 rats without the introduction of components relative to the preoperative parameters. However, it should be noted that these values remained within the physiological norm. In group 2, a decrease in $\mathrm{Hg}$ by 1.27 times $(\mathrm{p}=0.005)$ on day 7 and by 1.25 times $(p=0.002)$ on day 14 was observed. In group 3 with the paraossal administration of the component based on ethidronates of lanthanide and calcium and in group 4 with the introduction of the components based on calcium ethidronate (without lanthanide ions) through the catheter on day 7 , there was a similar decrease by 1.23 times ( $p=0,0001$, group 3; $p=0.028$, group 4) (Table 3).

Leukopenia (a twofold decrease in this indicator, $p=0.027)$ was recorded in the experimental animals with respect to the initial indicator in group 4 on day 14 .
In group 5 with the paraossal administration of calcium ethidronate (without lanthanide), a decrease (Table 4) in the number of leukocytes by 2.1 times $(\mathrm{p}=0.031)$ was recorded on day 30 (p. 4). Group 1 without the introduction of any component and group 3 with the paraossal administration of ethidronates of lanthanide and calcium underwent the smallest fluctuations within the physiological norm.

The number of erythrocytes (Er) significantly decreased on day 7 in group $1(p=0.017)$ and in group 2 with the introduction of the components based on the ethidronates of lanthanide and calcium through a catheter $(p=0.011)$. In group 4 of calcium ethidronate (without lanthanide) introduction through a catheter on day 14 , this indicator decreased by 1.3 times $(p=0.015)$ (Table 5). However, these indicators were within the physiological norm, also in the other groups.

Table 3

Change in the concentration of hemoglobin in the blood of animals $(\mathrm{g} / \mathrm{l})$

\begin{tabular}{|c|c|c|c|c|c|c|}
\hline Group /Term & Before operation & 7 days & Before operation & 14 days & Before operation & 30 days \\
\hline Group 1 & $188 \pm 7$ & $150 \pm 6^{*}$ & $207 \pm 10$ & $185 \pm 6$ & $202 \pm 5$ & $170 \pm 4^{*}$ \\
\hline Group 2 & $184 \pm 6$ & $144 \pm 3^{*}$ & $212 \pm 7$ & $169 \pm 10^{*}$ & $175 \pm 12$ & $178 \pm 5$ \\
\hline Group 3 & $186 \pm 2$ & $151 \pm 1^{*}$ & $210 \pm 10$ & $198 \pm 7$ & $179 \pm 6$ & $180 \pm 8$ \\
\hline Group 4 & $212 \pm 14$ & $171 \pm 11^{*}$ & $198 \pm 8$ & $164 \pm 14$ & $178 \pm 6$ & $175 \pm 6$ \\
\hline Group 5 & $171 \pm 11$ & $170 \pm 27$ & $182 \pm 4$ & $183 \pm 7$ & $167 \pm 17$ & $193 \pm 13$ \\
\hline
\end{tabular}

Notes: * - statistically significant differences with preoperative values at $\mathrm{p}<0.05$

Table 4

Change in the content of leukocytes in the blood of animals $\left(10^{9} / 1\right)$

\begin{tabular}{|c|c|c|c|c|c|c|}
\hline Group /Term & Before operation & 7 days & Before operation & 14 days & Before operation & 30 days \\
\hline Group 1 & $9.2 \pm 2.0$ & $8.1 \pm 1.2$ & $11.9 \pm 1.6$ & $10.1 \pm 1.1$ & $9.2 \pm 1.6$ & $8.3 \pm 1.4$ \\
\hline Group 2 & $10.1 \pm 0.9$ & $6.8 \pm 1.2$ & $10.5 \pm 1.4$ & $6.3 \pm 1.3$ & $14.8 \pm 2.0$ & $10.1 \pm 2.1$ \\
\hline Group 3 & $12.9 \pm 2.1$ & $10.9 \pm 0.6$ & $12.7 \pm 2.4$ & $10.5 \pm 0.7$ & $13.0 \pm 2.3$ & $11.7 \pm 3.0$ \\
\hline Group 4 & $12.6 \pm 3.4$ & $8.5 \pm 1.2$ & $16.4 \pm 2.6$ & $8.2 \pm 1.6 *$ & $13.2 \pm 2.2$ & $11.0 \pm 2.7$ \\
\hline Group 5 & $10.3 \pm 2.1$ & $7.3 \pm 1.8$ & $17.2 \pm 1.9$ & $10.1 \pm 1.6$ & $15.1 \pm 2.8$ & $7.1 \pm 1.4^{*}$ \\
\hline
\end{tabular}

Notes: ${ }^{*}$ - statistically significant differences with preoperative values at $\mathrm{p}<0.05$

Table 5

Change in the content of erythrocytes in the blood of animals $\left(10^{12} / 1\right)$

\begin{tabular}{|c|c|c|c|c|c|c|}
\hline Group /Term & Before operation & 7 days & Before operation & 14 days & Before operation & 30 days \\
\hline Group 1 & $6.1 \pm 0.1$ & $4.7 \pm 0.2^{*}$ & $6.1 \pm 0.3$ & $5.8 \pm 0.3$ & $6.3 \pm 0.4$ & $5.9 \pm 0.1$ \\
\hline Group 2 & $6.4 \pm 0.3$ & $4.5 \pm 0.3^{*}$ & $5.7 \pm 0.4$ & $5.5 \pm 0.3$ & $5.9 \pm 0.2$ & $6.0 \pm 0.2$ \\
\hline Group 3 & $5.8 \pm 0.2$ & $4.8 \pm 0.5$ & $7.0 \pm 0.2$ & $6.4 \pm 0.4$ & $6.6 \pm 0.3$ & $6.1 \pm 0.2$ \\
\hline Group 4 & $6.5 \pm 0.3$ & $5.9 \pm 0.4$ & $6.8 \pm 0.5$ & $5.2 \pm 0.6^{*}$ & $5.5 \pm 0.4$ & $5.6 \pm 0.2$ \\
\hline Group 5 & $5.8 \pm 0.3$ & $5.1 \pm 0.2$ & $6.0 \pm 0.3$ & $7.0 \pm 0.1$ & $5.2 \pm 0.3$ & $6.4 \pm 0.3$ \\
\hline
\end{tabular}

Notes: * - statistically significant differences with preoperative values at $\mathrm{p}<0.05$ 
On the $7^{\text {th }}$ day of the experiment, a decrease in the lymphocyte content in group 2 with the introduction of components based on the ethidronates of lanthanide ions and calcium through the catheter by $20 \%(p=0.004)$ and in group 3 with the paraossal administration of components based on the ethidronates of lanthanide and calcium by $27 \%(p=0.012)$ with respect to the preoperative values was revealed. Whereas on day 30 in group 1 without the introduction of the components, this indicator decreased by $22 \%(p=0.037)$. On the $14^{\text {th }}$ day, lymphocytopenia was observed in group 2 with the introduction of the components based on the ethidronates of lanthanide ions and calcium through a catheter and had a significant difference of $23 \%$ from group 5 with the paraossal administration of the components without lanthanide ions $(p=0.024)$ and from group 3 with the paraossal administration of the components containing lanthanide ions $(p=0.046)$, (Table 6). In group 4 with the introduction of the components without lanthanide ions through a catheter, a slight decrease in lymphocytes was observed over the entire period. In group 5 with the paraossal administration of the components based on calcium ethidronate (without lanthanide ions), the lymphocyte content remained almost unchanged throughout the experiment.A significant increase by $71 \%(p=0.041)$ in segmented neutrophils on day 30 in group 1 without the introduction of the components was revealed with respect to preoperative values. This indicator increased on days 7 and 14 in group 2 with the introduction of lanthanide ion component through the catheter by $56 \%$ $(\mathrm{p}=0.001)$ and $38 \%(\mathrm{p}=0.042)$, respectively.

On the $7^{\text {th }}$ day, the number of segmented neutrophils in group 3 with the paraossal administration of the components containing lanthanide ions increased by $66 \%(\mathrm{p}=0.005)$ and on the 30th day by $50 \%(\mathrm{p}=0.030)$ (Table 7). The nature of changes in this indicator in other groups did not have significant differences.

In group 5 with the paraossal administration of calcium ethidronate (without lanthanide ions) on day 7 , a significant decrease by $62 \%(p=0.044)$ was observed relative to group 3 with the paraossal administration of components based on the ethidronates of lanthanide ions and calcium.

On the $7^{\text {th }}$ day, the number of stab neutrophils in group 5 with paraossal administration of the components based on calcium ethidronate (without lanthanide ions) was increased by 3.7 times $(p=0.048)$ relative to the initial values. On the 14th day in group 4 with the introduction of the components based on calcium ethidronate (without lanthanide ions) through a catheter, a 2.4-fold decrease in this indicator was observed $(\mathrm{p}=0.025)$. On day 14 , a significant increase in the index in group 2 with the introduction of the components based on the ethidronates of lanthanide and calcium through a catheter was revealed by $75-95 \%(p=0.001)$ relative to other groups (Table 8$)$.

Table 6

Dynamics of the lymphocytes content in the blood of animals (\%)

\begin{tabular}{|c|c|c|c|c|c|c|}
\hline Group /Term & Before operation & 7 days & Before operation & 14 days & Before operation & 30 days \\
\hline Group 1 & $80.2 \pm 5.0$ & $83.6 \pm 4.6$ & $84.0 \pm 4.6$ & $84.0 \pm 5.5$ & $88.6 \pm 1.5$ & $69.2 \pm 6.4^{*}$ \\
\hline Group 2 & $81.6 \pm 2.6$ & $65.0 \pm 0.5^{*}$ & $76.8 \pm 3.1$ & $67.4 \pm 3.2 \#$ & $73.0 \pm 18.3$ & $86.6 \pm 3.9$ \\
\hline Group 3 & $83.2 \pm 1.5$ & $60.4 \pm 5.7^{*}$ & $85.6 \pm 2.3$ & $85.2 \pm 1.9$ & $85.2 \pm 0.9$ & $75.2 \pm 3.8$ \\
\hline Group 4 & $83.8 \pm 3.6$ & $70.2 \pm 8.8$ & $86.4 \pm 2.5$ & $83.6 \pm 4.5$ & $76.7 \pm 6.2$ & $68.7 \pm 7.4$ \\
\hline Group 5 & $87.2 \pm 1.6$ & $82.0 \pm 4.3$ & $84.4 \pm 1.2$ & $87.0 \pm 3.7$ & $72.6 \pm 7.3$ & $75.6 \pm 5.2$ \\
\hline
\end{tabular}

Notes: * - significantly significant differences with preoperative values at $\mathrm{p}<0.05$; \# - significantly significant differences between the values of group 2 and groups 3 and $5, p<0.05$

Table 7

Dynamics of the content of segmented neutrophilic granulocytes in the blood of animals (\%)

\begin{tabular}{|c|c|c|c|c|c|c|}
\hline Group /Term & Before operation & 7 days & Before operation & 14 days & Before operation & 30 days \\
\hline Group 1 & $16.8 \pm 4.5$ & $14.6 \pm 4.4$ & $13.6 \pm 3.9$ & $14.6 \pm 5.1$ & $8.0 \pm 1.0$ & $27.4 \pm 6.7^{*}$ \\
\hline Group 2 & $14.2 \pm 1.8$ & $32.6 \pm 0.8^{*}$ & $15.8 \pm 2.1$ & $25.4 \pm 3.0^{*}$ & $23.4 \pm 16.7$ & $11.2 \pm 3.5$ \\
\hline Group 3 & $12.2 \pm 1.5$ & $35.6 \pm 5.4^{*}$ & $10.4 \pm 2.7$ & $12.8 \pm 2.4$ & $10.2 \pm 0.8$ & $20.2 \pm 3.5^{*}$ \\
\hline Group 4 & $14.6 \pm 2.8$ & $24.6 \pm 7.5$ & $10.8 \pm 2.4$ & $12.6 \pm 3.3$ & $18.7 \pm 5.3$ & $25.0 \pm 6.4$ \\
\hline Group 5 & $10.6 \pm 1.3$ & $13.4 \pm 3.5 \#$ & $12.6 \pm 0.5$ & $9.6 \pm 2.9$ & $21.6 \pm 6.0$ & $20.6 \pm 4.7$ \\
\hline
\end{tabular}

Notes: * - significantly significant differences with preoperative values at $\mathrm{p}<0.05$; \# - significantly significant differences between the values of group 5 and group $3, \mathrm{p}<0.05$

Table 8

The dynamics of the content of stab neutrophilic granulocytes in the blood of animals at the stages of the study (\%)

\begin{tabular}{|c|c|c|c|c|c|c|}
\hline Group /Term & Before operation & 7 days & Before operation & 14 days & Before operation & 30 days \\
\hline Group 1 & $2.2 \pm 1.4$ & $1.2 \pm 0.3$ & $2.2 \pm 0.6$ & $0.6 \pm 0.2$ & $2.4 \pm 1.0$ & $2.8 \pm 0.5$ \\
\hline Group 2 & $3.0 \pm 0.9$ & $1.2 \pm 0.3$ & $5.0 \pm 2.1$ & $7.0 \pm 0.7 \#$ & $2.6 \pm 1.8$ & $1.8 \pm 0.6$ \\
\hline Group 3 & $3.2 \pm 0.5$ & $1.6 \pm 0.6$ & $1.6 \pm 0.6$ & $1.6 \pm 0.9$ & $2.8 \pm 1.1$ & $3.6 \pm 1.2$ \\
\hline Group 4 & $1.2 \pm 0.9$ & $3.0 \pm 0.7$ & $2.4 \pm 0.5$ & $1.0 \pm 0.3^{*}$ & $4.2 \pm 1.1$ & $5.2 \pm 1.1$ \\
\hline Group 5 & $0.8 \pm 0.3$ & $3.0 \pm 1.0^{*}$ & $1.4 \pm 0.6$ & $1.2 \pm 0.5$ & $4.6 \pm 1.6$ & $1.6 \pm 0.6$ \\
\hline
\end{tabular}

Notes: * - significantly significant differences with preoperative values at $\mathrm{p}<0.05$; \# - significantly significant differences between the values of group 2 and other groups, $\mathrm{p}<0.05$. 
Throughout the experiment, the monocyte count underwent insignificant changes in the animals and remained within the norm.

On the $14^{\text {th }}$ day, eosinopenia was established compared with preoperative data only in group 2 with the introduction of the components based on of the ethidronates of lanthanide and calcium ions through a catheter $(p=0.034)$. In animals of all groups throughout the experiment, basophils were absent in the blood.

\section{DISCUSSION}

It is well known that any organism reacts with any foreign body invading it, as a result of which the decay products "poison" it, causing inflammation and tissue rejection [21]. As our studies have shown, the method of introducing components through a catheter is ineffective. The groups of animals with introduction of the components had the most pronounced exudative process and an increased body temperature, which is the result of a foreign body (catheter) under the skin. Also, in these groups, changes in blood indices were more pronounced, and therefore, a correlation was observed in animals of these groups while analyzing clinical and hematological changes.

Features of the body's response to many pathological conditions are such that changes in the blood occur long before the first symptoms appear.

In the course of the study, it was found that the introduced components based on the ethidronates of lanthanide and calcium ions, intended to activate bone repair, lead to an increase in the erythrocyte sedimentation rate relative to preoperative values by 30 days. However, according to the literature data, it was found that this indicator can normally reach up to $1.5 \mathrm{~mm} /$ hour, whereas in our studies it was equal to $0.9 \pm 0.10 \mathrm{~mm} /$ hour, which is not a deviation [22]. Also, in these groups, at different observation periods, an increase in segmented neutrophils and a decrease in lymphocytes at the early (7 days) observation periods were noted, which may be associated with the body's response to trauma. By the end of the experiment (30 days), similar changes were observed in the group without components; however, they did not pass beyond the physiological norm. According to a number of studies, the boundary of the volatility of segmented neutrophils can reach $35 \%$ [23], and of the lymphocyte content 55-98 \% [23, 24].

Currently, there is some information about the effect of lanthanides on peripheral blood parameters [25]. Our analysis of hematological parameters revealed a slight decrease in the hemoglobin concentration in the early stages in all groups, as well as in the group with the paraossal administration of the components based on ethidronates of lanthanide and calcium, the indicators of which did not exceed the physiological norm. A group of authors conducted an experiment in which the effect of a contrast medium containing a lanthanide (gadolinium) was investigated. He showed that lanthanide did not cause significant changes in hemoglobin levels [26].

Analyzing the findings obtained by us it was found that the changes that occurred in the group during the paraossal administration of components containing lanthanide ions and in the group without the introduction of components changed identically. It was determined that the average content of erythrocytes and leukocytes in the experimental rats did not differ from those in animals of the group where the components were not administered.

For comparison, other authors conducted hematological studies on rabbits to study the effect of components containing lanthanides by their local introduction into the perforation defect. The studies found that the changes in the quantitative indicators of leukocytes and erythrocytes occurred mainly in the early stages, which may indicate the acute phase of the inflammatory process; however, these changes were similar both in the group without the introduction of components and in the group with the introduction of these components [27].

Summarizing the results of the study, we conclude that the observed changes in the group with the paraossal administration of the components containing lanthanide ions were insignificant, and returned to physiological values by the end of the experiment. In similar studies in rabbits, similar results were observed by double local introduction of lanthanides into the perforation defect, with no pathological changes in blood parameters [14].

\section{CONCLUSIONS}

Due to the fact that the changes in blood parameters in the experimental groups remained within the reference values and were similar to the values in group 1 , where the components were not introduced, it can be assumed that the revealed changes are characteristic of the body's response to surgery.

It was found that the content of eosinophils was within the physiological norm. It confirms the absence of an allergic reaction to the components and their doses.

The experimental results reflect the functional state of the animal organism by the introduction of the components based on ethidronates of lanthanide and calcium ions, as well as with the introduction of components based on calcium ethidronate (without lanthanides) into the fracture zone and are quite comparable with the findings of the previous studies [20,27, 28]. 


\section{REFERENCES}

1. Kozlov N.A. Stimuliatsiia osteoreparatsii u sobak [Stimulation of osteoreparation in dogs]. Veterinariia, 2000, iss. 6, pp. 54-55. (in Russian)

2. Silanteva T.A., Krasnov V.V. Stimuliatsiia zazhivleniia perelomov taza putem lokalnogo vvedeniia autologichnoi plazmy krovi v sochetanii s metabolicheski aktivnymi veshchestvami antioksidantnogo i antigipoksantnogo deistviia [Stimulation of pelvis fracture healing by local infusion of autologous blood plasma combined with metabolically active substances of antioxidant and antihypoxant action]. Vestnik Rossiiskoi Akademii Meditsinskikh Nauk, 2014, vol. 69, no. 7-8, pp. 137-143. (in Russian)

3. Kirpichev I.V., Maslov L.B., Korovin D.I. Aktualnye mezhdistsiplinarnye problemy primeneniia sovremennykh poristykh implantatov dlia zameshcheniia kostnykh defektov [Relevant interdisciplinary problems of using modern porous implants to replace bone defects]. Sovremennye Problemy Nauki i Obrazovaniia, 2016, no. 1. (in Russian) Available at: https://www.elibrary.ru/item.asp?id=25509249 (accessed 05.04.2019).

4. Kazakova V.S., Chuev V.P., Novikov O.O., Zhiliakova E.T., Fadeeva D.A. Ispolzovanie faktorov rosta v vosstanovlenii kostnoi tkani (obzor) [The use of growth factors in bone tissue restoration (Review)]. Nauchnye Vedomosti Belgorodskogo Gosudarstvennogo Universiteta. Seriia: Meditsina. Farmatsiia, 2011, no. 4-2 (99), iss. 13/2, pp. 5-12. (in Russian)

5. Barabash A.P., Shpiniak S.P., Barabash Iu.A. Sravnitelnaia kharakteristika metodov osteosinteza u patsientov s oskolchatymi perelomami diafiza bedrennoi kosti [Comparative characteristics of osteosynthesis methods in patients with comminuted fractures of the femoral shaft]. Travmatologiia i Ortopediia Rossii, 2013, no. 2 (68), pp. 116-124. (in Russian)

6. Beidik O.V., Annikov V.V., Kireev S.I., Levchenko K.K,, Van Kai, Markov D.A. Preimushchestva ispolzovaniia biomateriala alloplant pri zamedlenno konsolidiruiushchikhsia perelomakh i psevdoartrozakh trubchatykh kostei [Benefits of using alloplant biomaterials for delayed consolidating fractures and pseudoarthroses of tubular bones]. Genij Ortopedii, 2007, no. 3, pp. 85-88. (in Russian)

7. Larina V.N., Mikhailusova M.P., Raspopova T.N. Primenenie biokhimicheskikh markerov kostnogo obmena v povsednevnoi deiatelnosti vracha [The use of bone metabolism biochemical markers in the daily physician's activity]. Lechebnoe Delo, 2015, no. 2, pp. 10-14. (in Russian)

8. Pakhlevanian G.G., Pakhlevanian S.G. Vliianie preparata «Kollapan» na osteogenez pri defektakh na verkhnei cheliusti u cheloveka ["Collapan” preparation effect on osteogenesis for the maxilla human defects]. Nauchnyi Almanakh, 2016, no. 8-1 (22), pp. 303-305. (in Russian) DOI: 10.17117/na.2016.08.01.303.

9. Litvinov S.D., Krasnov A.F., Kulikov A.N. Primenenie kompozita «LitAr» v sluchae zamedlennoi konsolidatsii pereloma i lozhnogo sustava [Using "LitAr" composite in case of delayed consolidation fracture and pseudoarthrosis]. Biulleten Vostochno-Sibirskogo Nauchnogo Tsentra Sibirskogo otdeleniia Rossiiskoi Akademii Meditsinskikh Nauk, 2006, no. 5 (51), pp. 122-127. (in Russian)

10. Mironov S.P., Rodionova S.S., Lekishvili M.V. Biokompozitnyi material dlia osteoplastiki [Biocomposite material for osteoplasty]. Patent RF no. 2325170, 2006, Biul. no. 15, 7 pp. (in Russian)

11. Toroptsova N.V., Dobrovolskaia O.V., Nikitinskaia O.A. Lechenie osteoporoza v klinicheskoi praktike: fokus na bisfosfonaty [Osteoporosis treatment in clinical practice: focus on bisphosphonates]. Effektivnaia Farmakoterapiia, 2016, no. 17, pp. 6-10. (in Russian)

12. Lekishvili M.V., Sklianchuk E.D., Akatov V.S., Ochkurenko A.A., Gurev V.V., Raginov I.S., Bugrov S.N., Riabov A.Iu., Fadeeva I.S., Iurasova Iu.B., Chekanov A.S. Kostnoplasticheskie osteoinduktivnye materialy v travmatologii i ortopedii [Osteoplastic osteoinductive materials in traumatology and orthopaedics]. Genij Ortopedii, 2015, no. 4, pp. 61-67. (in Russian) DOI: 10.18019/1028-4427-2015-4-61-67.

13. Rukk N.S., Apryshko G.N., Skriabina A.Iu. Perspektivnost sozdaniia protivoopukholevykh lekarstv na osnove koordinatsionnykh soedinenii elementov IIIB-gruppy [The prospect of producing antitumor drugs based on coordination compounds of IIIB-group elements]. Rossiiskii Bioterapevticheskii Zhurnal, 2014, vol. 13, no. 2, pp. 47-50. (in Russian)

14. Akhtyamov I.F., Shakirova F.V., Kliushkina Iu.A., Baklanova A.D., Gatina E.B., Aliev E.O. Analiz regenerativnogo protsessa v oblasti pereloma bolshebertsovoi kosti (eksperimentalnoe issledovanie) [Analysis of the regenerative process in the area of tibial fracture (An experimental study)]. Travmatologiia i Ortopediia Rossii, 2016, vol. 22, no. 1, pp. 100-107. (in Russian)

15. Zhitlova E.A., Shakirova F.V., Akhtyamov I.F. Etapnaia kolichestvennaia otsenka reparativnogo osteogeneza pri indutsirovannoi travme [Stage quantification assessment of reparative osteogenesis for induced injury]. Veterinarnyi Vrach, 2015, no. 6, pp. 54-58. (in Russian)

16. Akhtyamov I.F., Shakirova I.F., Gatina E.B., Aliev E.I., Mechov M.P. KT-semiotika reparativnykh protsessov v bolshebertsovoi kosti pri intramedulliarnom osteosinteze implantatami s pokrytiem nitridami titana i gafniia v eksperimente [CT-semiotics of reparative processes in the tibia when performing intramedullary osteosynthesis using implants with the coating of titanium and hafnium nitrides experimentally]. Genij Ortopedii, 2015, no. 2, pp. 53-56. (in Russian)

17. Zhitlova E.A., Shakirova F.V. Kolichestvennaia etapnaia otsenka kostnogo regenerata v zone indutsirovannoi travmy pri vvedenii preparata na osnove difosfatov [Quantitative staged assessment of regenerated bone in the zone of induced injury when administrating the preparation based on diphosphates]. Ippologiia i Veterinariia, 2016, no. 3 (21), pp. 43-48. (in Russian)

18. Deviatov F.V., Kholmogortsev E.G. Sposob regeneratsii kostnoi tkani v eksperimente [The way of bone tissue regeneration experimentally]. Patent RF 2248210, 2003, Biul. no.8, 8 pp. (in Russian)

19. Zhitlova E.A. Vliianie preparata na osnove etidronatov lantanoidov i kaltsiia na izmenenie biokhimicheskikh pokazatelei syvorotki krovi u zhivotnykh s kostnym defektom [The effect of the preparation based on lanthanide etidronates and calcium on changing the blood serum biochemical values in the animals with a bone defect]. Izvestiia Orenburgskogo Gosudarstvennogo Agrarnogo Universiteta, 2016, no. 4 (60), pp. 108-110. (in Russian)

20. Zhitlova E.A., Shakirova F.V. Izmeneniia pokazatelei krovi i reaktsii regionarnykh limfaticheskikh uzlov pri vvedenii v defekty bolshebertsovoi kosti preparata na osnove etidronata lantanoida i kaltsiia $\mathrm{v}$ eksperimente [Changes in the blood values and the response of regional lymph nodes when infusing the preparation based on lanthanide etidronate and calcium into tibial defects experimentally]. Uchenye Zapiski Kazanskoi Gosudarstvennoi Akademii Veterinarnoi Meditsiny im. N.E. Baumana, 2016, vol. 227, no. 3, pp. 23-28. (in Russian)

21. Talashova I.A., Grebneva O.L. Kaltsiifosfatnye materialy v rekonstruktivno-vosstanovitelnoi khirurgii [Calcium-phosphate materials in reconstructive-and-restorative surgery]. Genij Ortopedii, 2002, no. 4, pp. 129-134. (in Russian)

22. Abrashova T.V., Gushchin Ia.A., Kovaleva M.A., Rybakova A.V., Selezneva A.I., Sokolova A.P., Khodko S.V. Physiological, biochemical and biometric values of the norm of experimental animals. Reference book. V.G. Makarov, M.N. Makarova, eds. SPb., Lema, 2013,116 p. (in Russian)

23. Motuzko N.S., Nikitin Iu.I., Martseniuk A.P., Pinchuk V.F. Spravochnik kliniko-biologicheskikh pokazatelei zhivotnykh [Handbook of clinical-andbiologic indicators of animals]. Gorki, 2001, 72 p. (in Russian)

24. Smith C.N., Neptun D.A., Irons R.D. Effect of sampling site and collection method on variations in baseline clinical pathology parameters in Fischer-344 rats. II. Clinical hematology. Fundam. Appl. Toxicol., 1986, vol. 7, no. 4, pp. 658-663. DOI: 10.1016/0272-0590(86)90115-6.

25. Akgun H., Gonlusen G., Cartwright J. Jr., Suki W.N., Truong L.D. Are gadolinium-based contrast media nephrotoxic? A renal biopsy study. Arch. Pathol. Lab. Med., 2006, vol. 130, no. 9, pp. 1354-1357. DOI: 10.1043/1543-2165(2006)130[1354:AGCMNA]2.0.CO;2.

26. Goldstein H.A., Kashanian F.K., Blumetti R.F., Holyoak W.L., Hugo F.P., Blumenfield D.M. Safety assessment of gadopentetate dimeglumine in U.S. clinical trials. Radiology, 1990, vol. 174, no. 1, pp. 17-23. DOI: 10.1148/radiology.174.1.2403679.

27. Shakirova F.V., Zhitlova E.A. Izmenenie gematologicheskikh pokazatelei eksperimentalnykh zhivotnykh pri vvedenii preparata na osnove etidronatov lantanoidov $\mathrm{i}$ kaltsiia $\mathrm{v}$ defekt bolshebertsovoi kosti [Changing the hematological values of experimental animals in case of infusing the preparation based on lanthanide etidronates and calcium into the tibial defect]. Vestnik Altaiskogo Gosudarstvennogo Agrarnogo Universiteta, 2016, no. 5 (139), pp. 149-152. (in Russian)

28. Boichuk S.V., Zhitlova E.A., Shakirova F.V., Tsyplakov D.E., Akhtyamov I.F., Deviatov F.V., Ramazanov B.R., Zakirov R.Kh. Kompleksnyi podkhod k izucheniiu preparata, soderzhashchego etidronaty ionov lantanoidov i kaltsiia, in vitro i in vivo [Complex approach to studying the preparation containing etidronates of lanthanide and calcium ions, in vitro and in vivo]. Genij Ortopedii, 2019, vol. 25, no. 4, pp. 561-568. (in Russian) DOI: 10.18019/1028-4427-2019-25-4-561-568.

Received: 28.02 .2020

\section{Information about authors:}

1. Ildar F. Akhtyamov, M.D., Ph.D., Professor, Kazan State Medical University, Kazan, Russian Federation, Email: yalta60@mail.ru

2. Faina V. Shakirova, M.D., Ph.D., associate professor,

Bauman Kazan State Academy of Veterinary Medicine, Kazan, Russian Federation,

Email: shakirova-fv@yandex.ru

3. Darya A. Korobeynikova,

Bauman Kazan State Academy of Veterinary Medicine, Kazan,

Russian Federation,

Email: korobejnikowa.darya2015@yandex.ru
4. Hao Zhi Han,

Kazan State Medical University, Kazan, Russian Federation, Email: hanhaozhi723@hotmail.com

5. Egor I. Sidoruk,

Kazan State Medical University, Kazan, Russian Federation, Email: ego7@list.ru 